DOI 10.4467/2543733XSSB.20.001.12197

\title{
INSTYTUCJONALNE PRZEOBRAŻENIA PRAKTYK MUZEALNYCH - PRZYPADEK MUZEUM (HISTORII) JUGOSŁAWII W BELGRADZIE
}

\author{
Institutional Transformations of Museum Practices - the Case of the Museum \\ of Yugoslavia in Belgrade
}

Summary

The article deals with institutional transformations of the Museum of Yugoslavia in Belgrade and their influence on the exhibition policy and practice of institution. Belgrade museum, initially functioning as a spatial and symbolic centre of Yugoslav political religion focused on the cult of Josip Broz Tito, today tries to realize the formula of a modern historical museum focused on the deconstruction of a mythologized image of socialist Yugoslavia and a critical presentation of the discourse of remembrance of this experience. The aim of the article is to answer the question regarding what mechanisms enabled this kind of transformation and how the Museum of Yugoslavia, while developing the post-Yugoslavian symbolic space, became an important actor of social processes acting not only in the field of tourism, but also in the field of the culture of knowledge and in the sphere of identity policies.

Keywords: Museum of Yugoslavia, system transformation, institutionalisation, culture of knowledge, exhibition practices, museum discourse

Słowa kluczowe: Muzeum Jugosławii, transformacja systemowa, instytucjonalizacja, kultura wiedzy, praktyki wystawiennicze, dyskurs muzealny

\section{Muzealizacja jako ramowanie}

Jednym z kluczowych wyzwań transformacji ustrojowej w krajach postsocjalistycznych stała się rewizja pamięci społecznej wraz z przebudową jej instytucjonalnych form. Doniosłą rolę w tym procesie odgrywa (re)konstrukcja kulturowej mapy ośrodków muzealnych, 
czyli działanie, które w wyrazisty sposób odzwierciedla kierunki weryfikacji dotychczasowych i tryby ustanawiania nowych polityk pamięci. Pluralizacja tego pola aktywności społecznych jest pochodną przewartościowania wzorów pojmowania i traktowania sfery publicznej, potrzeby podważenia i zanegowania hegemonii jednej idei, jednej racji politycznej, jednej, spetryfikowanej i zamkniętej formuły tożsamości ${ }^{1}$. Stawką jest tu uwolnienie pejzażu kulturowego polis spod hegemonii oficjalnej narracji historycznej oraz związanej z nią estetyki, będącej wyrazem określonego sposobu pojmowania polityczności.

W tym dążeniu wyraża się złożona konfiguracja procesów społecznej zmiany, określanej mianem transformacji demokratycznej. Nieprzypadkowo w toku tego procesu kładzie się nacisk na muzea, ponieważ katalizatorem i nośnikiem przeobrażeń sygnowanych mianem demokratyzacji stają się instytucje koordynujące obszar wiedzy, które sprawują kontrolę nad praktyką i ekonomią symboliczną społeczeństw². A zatem przemyślenie na nowo i przeprojektowanie muzeów - ich formuły wystawienniczej oraz społecznej roli - nieodłącznie musi się dziś wiązać z rozpoznaniami dotyczącymi (po)nowoczesnej kultury wiedzy, która coraz bardziej świadomie szuka oparcia w zinstytucjonalizowanych formach działania, a jednocześnie pozostaje silnie uwikłana w stosunki władzy. Co więcej, to właśnie kultura wiedzy - rozumiana jako domena lokalnych (tj. lokalnie wytworzonych lub zaadaptowanych oraz uwewnętrznionych) wartości, dyskursów, sposobów myślenia i przetwarzania informacji ${ }^{3}$ - staje się dziś jednym z ważniejszych wyznaczników polityki społecznej i przestrzennej w postsocjalistycznych (i nie tylko) państwach.

$\mathrm{Na}$ gruncie serbskim doskonałym ucieleśnieniem charakterystycznych dla regionu tendencji transformacyjnych, którego analiza pozwala uchwycić specyfikę ich instytucjonalnego aspektu, jest Muzeum Jugosławii (Muzej Jugoslavije) w Belgradzie. Łączące w sobie funkcje komemoracyjne mauzoleum Josipa Broz Tity oraz dokumentacyjno-wystawiennicze muzeum historycznego od przeszło dwóch dekad podlega intensywnym przeobrażeniom, które z jednej strony mają specyficzną motywację polityczną, a także pozostają silnie osadzone w lokalnym doświadczeniu społeczno-kulturowym, z drugiej zaś w partykularny sposób odwzorowują globalne przemiany tego, co publiczne, oraz przekształcenia zachodzące współcześnie w obszarze praktyk muzealnych.

Muzeum Jugosławii można uznać za centralny podmiot procesu instytucjonalizacji społecznej sukcesji jugosłowiańskiego państwa nie tylko w Serbii, ale także w wymiarze regionalnym. Istotą tego procesu jest zagospodarowanie i regulacja obszarów pamięci niewygodnej, spornej czy też niechcianej, a w związku z tym marginalizowanej i wymazywanej. Domeną rewizji staje się tu zatem sfera społecznej wyobraźni, pole idei i przedstawień kulturowych, które podlegają ciagłej weryfikacji, negocjacjom i aktualizacji, zaś stawką tego działania są wybory światopoglądowe i tożsamościowe. Dynamika interesującej mnie instytucjonalnej zmiany pamięci podpowiada przyjęcie perspektywy badawczej, której podstawowe założenia wyznacza performatyka. Otóż podejście performatywne pozwala konceptualizować zjawisko instytucjonalizacji pamięci w jego procesualności, liminalności i sprawczości, zależnych od złożonej konfiguracji uwarunkowań historycznych

\footnotetext{
${ }^{1}$ Por. M. Šuvaković, Farenhajt 387. Teorijske ispovesti, Novi Sad 2006, s. 85.

${ }^{2}$ E. Rewers, Kulturowa ekonomia miast, [w:] Kultura wiedzy, red. P. Celiński, J. P. Hudzik, Kraków 2012, s. 77.

${ }^{3}$ J. P. Hudzik, Wariacje na kulture wiedzy, [w:] Kultura wiedzy, s. 13.
} 
i społecznych. Dostrzegam w nim zatem nie tyle czynność rekonstrukcji czy kultywacji przeszłości, ile przede wszystkim praktykę społeczną, polegającą na ciagłym wytwarzaniu pamięci i wiedzy o minionej epoce. Instytucjonalizację w ujęciu performatywnym dobrze oddaje kategoria ramowania, nazywająca - według Teresy Pękali - ,proces, który uwzględnia zdarzenie, wydobywa procesualność wyboru, zauważa ruch ujmowania w ramę oraz zatrzymanie, a zaraz po nim trwanie tego, co »tu i teraz « zostało ujęte w ramę"4. W owej społecznej procedurze instytucjonalizacji jako ramowania za szczególnie istotny uważam ten jej aspekt, który można nazwać „filozofią działania instytucji”, a więc pracę myśli, która określa i uprawomocnia istnienie i rozwój danej placówki, tłumaczy jej miejsce w konfiguracji aktywności kulturowych. W zajmującym mnie przypadku tematycznego muzeum historycznego materializuje się ona w postaci przedsięwzięć wystawienniczych oraz okołowystawienniczych, jest odpowiedzią na oficjalną politykę pamięci, instrumentem porządkowania społecznego imaginarium wokół doświadczenia historycznego, a także decyduje o strategiach uczestnictwa w sferze publicznej.

Namysł nad kulturowym znaczeniem Muzeum Historii Jugosławii, rozpatrywanym przez pryzmat kategorii procesu i zmiany, uruchamia szereg kluczowych pytań. Po pierwsze, o przyczyny, kierunek, przebieg oraz ideologiczne zaplecze transformacji tej placówki, po drugie zaś o jej aktualną kondycję i wspomnianą wyżej filozofię działania. Dawniej pełniąca funkcję ,politycznego sanktuarium”, miejsce kultu charyzmatycznego przywódcy państwa, ośrodek jugosłowiańskiej tanatopolityki i miejsce kohezji wielonarodowej wspólnoty, dziś dąży do wypracowania i wdrożenia nowoczesnej formuły muzeum jako instytucji dyskursywnej, krytycznej, która reaguje na politykę historyczną i wizerunkową miasta, państwa i regionu, a także ją współtworzy. Za sprawą tych zabiegów ma aspiracje stać się nie tylko ważnym punktem na mapie turystycznej kraju i regionu, ale także istotnym aktorem działającym w obszarze kultury wiedzy, regulatorem tzw. codziennego urbanizmu, czyli animatorem nowych sposobów bycia w mieście i partycypacji w miejskości. Z losami Muzeum Jugosławii nieodłącznie wiąże się także pytanie o możliwość i ewentualne strategie scalania świata po rozpadzie, choćby akt ten miał się dokonać tylko w sferze symbolicznej, w przestrzeni „wiedzy o”.

\section{Rytualizacja w funkcji instytucjonalizacji}

W skład Muzeum Jugosławii obok typowo wystawienniczego budynku Muzeum 25 Maja wchodzi także mauzoleum Josipa Broza Tity, zwane Domem Kwiatów (Kuća cveća) ${ }^{6}$, a także obiekty rezydencyjne - Dom Owalny (Ovalna zgrada), dawna sala bilardowa, Domek Myśliwski (Lovačka kuća), Stare Muzeum-Archiwum. Memorialno-muze-

${ }^{4}$ T. Pękala, Performans i teatralizacja-pojęcia wędrujace, [w:] Teatr, teatralizacja, performatywność, red. T. Pękala, Lublin 2016, s. 150.

${ }^{5}$ Odwołuję się tu do pojęcia tanatopolityki, oznaczającego sposoby wykorzystania śmierci w celach politycznych poprzez przypisywanie jej określonych ideologicznych sensów i wartości, które omawia szczegółowo Todor Kuljić w książce Tanatopolitika. Socijološkoistorijska analiza političke upotrebe smrti, Beograd 2014.

${ }^{6}$ Л. Стевановић, Реконструкција сећанја, конструкција памћенја. Кућа иъвћа и Музеј историје Југославије, „Зборник Етнеграфског института САНУ”, бр. 26: Спомен места - историја - сећања, уред. А. Павићевић, Београд 2009, с. 101-116; M. Bogusławska, Kuća na promaji. Szkic o mauzoleum Josipa Broza 
alny kompleks usytuowany jest w parkowym otoczeniu wzgórza Topčider, z którego rozpościera się widok na centralną część Belgradu. Według Aleksandra Ignjatovicia obiekt można uznać za ucieleśnienie polityczno-ideologicznej zasady konstytuującej model przywództwa oraz ustrój socjalistycznego państwa jugosłowiańskiego, której wyrazem w tym wypadku była koncepcja przestrzenna oparta na kontaminacji ,hierarchicznej i populistycznej przestrzeni mocy"'. Otwarte, publiczne tereny parkowe, a zwłaszcza znajdujący się w pobliżu Stadion Jugosłowiańskiej Armii Ludowej (gdzie oprócz standardowych wydarzeń sportowych co roku 25 maja z okazji Dnia Młodości oraz urodzin Josipa Broza organizowano pompatyczne widowisko masowe, doroczny rytuał legitymizujący i podtrzymujący ludową władzę), w intencjonalny sposób naruszały elitarny charakter tego tradycyjnie zamkniętego, odizolowanego obszaru Belgradu' .

Mimo że w nazwie placówki znajduje się określenie Jugosławia, to jednak geneza muzeum oraz bezpośrednia obecność grobu Tity decydują o koncentracji działalności wystawienniczej (a także archiwalno-badawczej) na tematyce związanej z okresem socjalizmu oraz jego aktualną recepcją (akcydentalnie wprowadzana jest tematyka tzw. pierwszej i trzeciej, Miloševiciowskiej Jugosławii). Nie tylko organizowane tu ekspozycje bądź związane z nimi aktywności kolekcjonerskie, dokumentacyjne i badawcze, ale również losy samej instytucji odzwierciedlają logikę reprezentacji, a następnie dramaturgię pamiętania i zapominania o socjalistycznej Jugosławii - specyficzny puls funkcjonowania jej społecznego obrazu przez przeszło pół wieku, ściśle zależny zarówno od przemian politycznych oraz ideologicznych, jak również złożonych procesów ekonomicznych i cywilizacyjnych.

Muzeum 25 Maja, stanowiące dziś organizacyjną podstawę kompleksu muzealno-memorialnego, zostało otwarte w 1962 roku i, według oficjalnej formuły, ofiarowane prezydentowi w darze przez stołeczne miasto $\mathrm{z}$ okazji jego siedemdziesiatych urodzin. Główne cele powołanej do życia z inicjatywy Rady Ludowej Miasta Belgradu (Narodni odbor grada Beograda) instytucji wyznaczyła potrzeba systematycznego gromadzenia i ochrony darów, które w czasie swoich rządów Josip Broz otrzymywał od zagranicznych dostojników państwowych (m.in. Winstona Churchilla, Józefa Stalina, Johna Kennedy’ego, Mao Tse Tunga, Fidela Castro) oraz innych osobistości z kraju i z zagranicy, a także w hołdzie od zwykłych obywateli z różnych stron federacji. W akcie założycielskim zaznaczono, że muzeum ma otoczyć pieczą wszelkie przedmioty o materialnej i duchowej wartości poświęcone Ticie lub związane z nim w każdy inny sposób - ordery, mundury, fotografie, auta, broń myśliwska, zegary, porcelanowe serwisy, biżuterię, dewocjonalia (sic!) itp. ${ }^{9}$ W ten sposób podstawą muzealnej kolekcji stały się przedmioty unikatowe, luksusowe, ekskluzywne, często artystyczne, mające niepodważalne znaczenie historyczne i kulturowe (jak zabytkowa szabla - prezent od Józefa Stalina czy księżycowy kamień - dar od Richar-

Tity, [w:] Znaczqce przestrzenie Stowiańszczyzny, red. J. Goszczyńska, G. Szwat-Gyłybowa, Warszawa 2010, s. $53-95$.

${ }^{7}$ A. Ignjatović, Tranzicija i reforme: architektura u Srbiji 1952-1980, [w:] Istorija umetnosti u Srbiji u XX veku, t. 2: Realizmi i modernizmi oko hladnog rata, Beograd 2012, s. 706.

${ }^{8}$ Ibidem.

${ }^{9}$ Decyzja o otwarciu Muzeum 25 Maja przyjęta 4.05.1962 r., Archiwum Muzeum Historii Jugosławii, za: M. Cvijović, Uzdarja J. B. Tita kao sastavni deo razmene poklona praćena kroz arhivsku građu i protokole kabineta predsednika republike, maszynopis udostępniony przez autora, Beograd 2011, s. 5. 
da Nixona), ale także rzeczy codziennego użytku, często pochodzące z seryjnej produkcji, pozbawione realnej wartości historyczno-muzealnej, będące w istocie rzeczy rodzajem wotów.

Wszystkie te artefakty, zanim stały się podstawą programu muzealnej reprezentacji przeszłości, stanowiły rekwizyt władzy i jako takie uczestniczyły - i nadal uczestniczą w procesach wytwarzania, kultywacji i popularyzacji (pośmiertnego) wizerunku jugosłowiańskiego prezydenta. Stanowią także materię badań historycznych, socjologicznych, antropologicznych, impuls dla naukowego namysłu np. nad charakterystyczną dla kultury władzy i dyplomacji zrytualizowaną praktyką wymiany darów, w którą „włożono tak wiele wysiłku i pieniędzy, a od której ani jedna, ani druga strona nie stała się bogatsza"10. Przede wszystkim jednak ogromne zbiory są racją istnienia i podstawą działalności ekspozycyjnej MHJ od początków funkcjonowania tej instytucji. Sam budynek Muzeum 25 Maja - wykonany według projektu uznanego architekta, Mihaila Miki Jankovicia ${ }^{11}$, wraz ze zdobiącą fasadę stylizowaną mozaiką autorstwa Bogdana Karanovicia, przedstawiająca symbolicznie, poprzez twórcze nawiązanie do ikonografii antycznej, ideę ludowej rewolucji - uznawany jest z uwagi na wpisane w architektonikę przeznaczenie oraz na walory estetyczne za ikoniczne dokonanie jugosłowiańskiej architektury modernistycznej drugiej połowy XX wieku.

Wybudowany w 1975 roku Dom Kwiatów, pomyślany jako zimowa oranżeria i obiekt rekreacyjny przeznaczony dla prezydenta, został usytuowany w pobliżu rezydencji, w otoczeniu parku będącego jednocześnie otwartą galerią rzeźby jugosłowiańskiej - wszystkie zgromadzone tu dzieła są darem artystów dla marszałka. Zgodnie z życzeniem Tity, który od czasu wizyty w USA w 1960 roku pozostawał pod wielkim wrażeniem Rose Garden (podobieństwo nazw obu obiektów nieprzypadkowe), czyli miejsca pochówku Franklina Roosevelta w Hyde Parku, pawilon oranżeryjny po śmierci jugosłowiańskiego prezydenta zmienił swoje pierwotne przeznaczenie ${ }^{12}$. W jego wnętrzu ulokowano grobowiec $\mathrm{z}$ białego marmuru, w którym umieszczono trumnę ze zwłokami Josipa Broza, a obok, w niskich parkowych pawilonach urządzono stałe ekspozycje. W gablotach usytuowanych w bezpośredniej bliskości grobu wystawiono pałki sztafetowe, gromadzone od początku uroczystych obchodów Dnia Młodości. Stanowiły one centralny rekwizyt tego kulminacyjnego w jugosłowiańskim kalendarzu święta oraz symbol idei braterstwa i jedności narodów Jugosławii $^{13}$. W pozostałych pomieszczeniach artefakty wybrane z kolekcji darów - egzotyczne suweniry, dzieła sztuki, ekskluzywne bibeloty, ale też ludowe rzemiosło oraz przedmioty

${ }^{10}$ Ibidem, s. 9. W tym miejscu należy wspomnieć wystawę DO, UT DES, zorganizowaną przez MHJ w 2002 roku, podczas przygotowania której została odnaleziona i wstępnie opracowana obszerna dokumentacja nt. darów, które Josip Broz otrzymywał, ale też wręczał. Gabinet Prezydenta Republiki prowadził ją systematycznie od początku swego istnienia, tj. od 1953 roku, do śmierci marszałka w1980 roku. Ibidem, s. 6.

${ }^{11}$ Mihailo Mika Janković (1911-1976) w okresie drugiej Jugosławii projektował reprezentacyjne obiekty państwowe w Belgradzie, takie jak Pałac Federacji i budynek Komitetu Centralnego KPJ (oba w dzielnicy Nowy Belgrad), a także znajdujący się nieopodal Muzeum Historii Jugosławii Stadion Jugosłowiańskiej Armii Ludowej (obecnie należący do klubu piłkarskiego „Partizan”), na którym od lat 50. rokrocznie 25 maja organizowano monumentalne uroczystości z okazji Dnia Młodości i przypadających na tę samą datę urodzin Tity.

12 Л. Стевановић, Реконструкиија..., 103.

${ }^{13}$ Zob. m.in. I. Čolović, Beograd: O maketama i štafetama, [w:] vlasTito iskustvo past present, R. Leposavić, Beograd 2005, s. 137-162 (polski przekład I. Čolović, O makietach i sztafetach, przeł. M. Petryńska, „Herito. Dziedzictwo, kultura, współczesność", 2012, nr 7, s. 112-121). 
codziennego użytku wykonane specjalnie z myślą o przywódcy otaczanym przez Jugosłowian, również po śmierci, quasi-religijnym kultem.

W efekcie tych działań w 1982 roku kompleks budynków prezydenckich i rozległy obszar parkowy w dzielnicy Dedinje został przekształcony w Centrum Memorialne im. Josipa Broza Tity (Memorialni centar „Josip Broz Tito”). Dwa lata później parlament SFRJ przegłosował wprowadzenie specjalnej ustawy, ściśle określającej zasady wykorzystania imienia i wizerunku Josipa Broza Tity. Dokument ów nadawał instytucjonalny kształt pośmiertnemu kultowi marszałka, regulował sposoby jego wykorzystania i oddawał pod kuratelę władz państwowych ${ }^{14}$. Zogniskowany wokół zmitologizowanej i gloryfikowanej „postaci i czynów” zmarłego przywódcy tanatopolityczny program jego sukcesorów stał się treścią jugosłowiańskiej religii politycznej, stanowiącej w obliczu pogłębiającego się kryzysu ekonomicznego oraz narastających konfliktów narodowościowych podstawowe spoiwo federacji. Z oczywistych względów rola centralnego sanktuarium przypadła Domowi Kwiatów oraz Muzeum 25 Maja, a instytucjonalizacja społecznej pamięci o Josipie Brozie Ticie przybrała formę komemoratywnych praktyk rytualnych, przede wszystkim tu właśnie celebrowanych.

W okresie politycznej aktywności Josipa Broza, a następnie, po jego śmierci, w warunkach pogłębiającego się kryzysu federacyjnego państwa, nieuchronnie zmierzającego ku katastrofie, praktykowanie rytuałów kohezji, takich jak podtrzymujące jugosłowiański mit: Dzień Młodości z biegiem sztafetowym jako jego centralnym punktem czy kultywacja rocznic śmierci przywódcy oraz świąt upamiętniających tzw. partyzancką walkę narodowowyzwoleńczą - stało się jednym z głównych narzędzi regulowania emocji społecznej i petryfikacji kolektywnego imaginarium. Rytualizacja służąca porządkowaniu i kontroli pamięci po śmierci Tity kładła akcent na zachowania zbiorowe, co ugruntowywało wyobrażenie o ludowym i masowym charakterze kultu marszałka i wzmacniało więź między społeczeństwem a państwem. Cyklicznie ponawiany społeczny performans sprzyjał ponadto swoistej sakralizacji pamięci o zmarłym przywódcy - grób i muzeum stały się m.in. celem pielgrzymek (obowiązkowo delegacji partyjnych, szkolnych wycieczek oraz mniej lub bardziej sformalizowanych odwiedzin grupowych i indywidualnych). Warunkiem żywotności i kulturowej siły państwowego kultu (nazywanego przez krytyków Titowską nekrokracją), w którym upatrywano gwarancji trwałości jugosłowiańskiego projektu politycznego, była społeczna identyfikacja ze stanowiącą jego rację bytu zmitologizowaną narracją, wyniesioną do rangi credo.

Jednocześnie upostaciowana w cyklicznych świętowaniach „retoryka odtwarzania”15 mogła wydawać się sprzeczna z logiką nowoczesności, stanowiącą wszakże rdzeń organizacyjnych podstaw państwa jugosłowiańskiego. Nowoczesność bowiem, jak twierdzi Paul Connerton, immanentnie wyklucza ideę życia jako struktury uroczystych powtórzeń ${ }^{16}$. Jednak tę wynikającą z anachronizmu kolizję doskonale zdawała się neutralizować właśnie instytucja muzeum. Pojmowana tradycjonalistycznie jako forma konserwująca i uhistoryczniająca przekaz kulturowy w warunkach nowoczesności, nastawionej na zmianę, tym-

14 Указ о прогламењу закона о употреби имена и лика Јосипа Броза Тита, „Службени лист Социјалистичке Федеративне Републике Југославије”, 28.09.1984, год. XL, бр. 51, с. 1179-1181.

${ }^{15}$ P. Connerton, Jak społeczeństwa pamiętaja, przeł. M. Napiórkowski, Warszawa 2012, s. 137.

${ }^{16}$ Ibidem, s. 133. 
czasowość i doraźność, miała wszelkie prerogatywy, by w zlaicyzowanej rzeczywistości socjalistycznego państwa uzasadniać praktykę zrytualizowanej komemoracji, stając się z jednej strony formą pomnika nobilitującego i afirmującego przeszłość oraz jej symboliczne przesłanie jako wartość, z drugiej zaś pełniąc funkcje sanktuarium wskazujące na quasi-religijne fundamenty jugosłowiańskiej kultury politycznej.

Jeśli zatem belgradzkie muzeum, samo w sobie uosabiające ideę niezmienności w naznaczonych ciagłą metamorficznością realiach, zostało powołane do tego, by być dysponentem i koordynatorem społecznego celebrowania jugosłowiańskiej (idei) wspólnotowości, to erozja i dezawuacja tego rytuału - będąca symptomem kryzysu i postępującego rozpadu Jugosławii, szybko wykazały, że celebracja powtórzenia w społeczeństwie nowoczesnym ma inny status niż w społecznościach tradycyjnych. Jak twierdzi Connerton, jest ona nie tyle sposobem aktualizacji jakości mitycznych, ile narzędziem kompensacji. Współczesne rytuały zamiast identyfikacji typu mitycznego oferują doświadczenie trwałości formalnej struktury, będącej ramą ideologicznych treści ${ }^{17}$. A zatem jej destrukcja, która przybrała skrajną postać rozpadu SFRJ, unieważniła konstytuującą państwowy rytuał narrację i podważyła rację istnienia instytucji odpowiedzialnej za odnawianie i społeczne zagospodarowanie kapitału symbolicznego przeszłości. Muzeum zaprojektowane i funkcjonujące w pierwszym okresie jako centrum, w którym koncentruje się, manifestuje i odnawia na co dzień rozproszona energia społeczna, szybko zaczęło się przeobrażać w przedmiot sporu i negacji, co znamienne - nie tyle jako pomnik komunizmu (jak się działo w tym czasie z podobnymi obiektami w innych krajach postkomunistycznych), ile jako symbol „,braterstwa i jedności” narodów Jugosławii, jako znak jedności. Pogłębiający się w latach dziewięćdziesiątych kryzys placówki stał się najbardziej spektakularnym przykładem zmian zachodzących w topografii pamięci społecznej.

\section{Deinstytucjonalizacja}

Po rozpadzie Jugosławii pozycja Kompleksu Memorialnego im. Josipa Broza Tity, którego istnienie motywowała potrzeba legitymizacji zasad funkcjonowania wieloetnicznej federacji - opartych na socjalizmie jako obowiązującym ustroju politycznym, a także symbolicznego usankcjonowania dożywotnich rządów Josipa Broza, uległa silnemu zachwianiu. Placówka okazała się miejscem problematycznym, budzącym kontrowersje etyczne i skrajne odczucia pomnikiem, trudnym do zatarcia śladem minionego. Fakt, że centralnym punktem kompleksu jest grób, a więc miejsce objęte społecznym tabu, ze zrozumiałych względów stanowił czynnik dodatkowo komplikujący sytuację. Grobowiec nadaje wszakże całemu obiektowi swoiście sakralny, by nie powiedzieć, epifaniczny ${ }^{18}$ wymiar i wyposaża przestrzeń w znaczenia symboliczne - mimo intencjonalnie świeckiego charakteru pochówku, mające odniesienia wertykalne ${ }^{19}$. Do legendy przeszła zorgani-

\footnotetext{
17 Ibidem.

${ }^{18}$ Odczucie tej epifaniczności wyjątkowo silnie przybliżają osobiste listy adresowane do Tity, pozostawiane przez pielgrzymujących przy sarkofagu marszałka.

${ }^{19}$ Warto nadmienić, że 2013 roku w Domu Kwiatów obok grobowca Tity ustawiono jeszcze jeden sarkofag. Została w nim pochowana (jako była partyzantka zgodnie z ceremoniałem wojskowym) żona marszałka, Jovanka Broz. Fakt ten przypieczętował status miejsca pochówku jako obiektu funeralnego, objętego urzędową opieką
} 
zowana przed Domem Kwiatów w rocznicę śmierci Tity 4 maja 1991 roku przez przedstawiciela Serbskiej Partii Radykalnej Voislava Šeselja demonstracja, podczas której domagano się przeniesienia zwłok marszałka do rodzinnego Kumrovca w Chorwacji i przekształcenia muzeum w ośrodek rekreacyjno-turystyczny. Uczestnicy manifestacji w czetnickich mundurach z osikowymi kołkami w dłoniach i przy wtórze serbskich pieśni patriotycznych odgrażali się, że zaatakują grób (chorwackiego), ,wampira”, żerującego na kolektywnym ciele serbskiego narodu ${ }^{20}$. Przekształcona w karnawał serbskiego nacjonalizmu ,šešeljada” była spektakularną próbą naruszenia tabu grobu i odrzucenia depozytu pamięci stanowiącego rację bytu muzeum.

Centrum muzealne na Wzgórzu Topčiderskim - przez jednych otaczane troską jako obszar kultu, przez innych negowane jako miejsce upamiętniające autorytarne rządy komunistycznego przywódcy, wciąż jednak pozostawało miejscem głęboko zakotwiczonym w kulturowym krajobrazie Belgradu. Z tego względu od dramatycznego początku transformacji systemowej było włączone w tryby na nowo uruchomionej społecznej machiny pamięci i zapomnienia, którą podporządkowano obowiązującej opcji polityczno-ideologicznej, forsowanej przez Miloševicia i sprzyjające mu kręgi, a także wpisanej w nią narracji historycznej. W wyniku podziału strukturalnych i instytucjonalnych podwalin państwa, a także w konsekwencji zanegowania identyfikacji ze wspólnotowym dziedzictwem socjalistycznej Jugosławii zgodnie z dominującą polityką różnicy, instytucja reprezentująca kraj, który przestał istnieć, utraciła swą legitymację. Na początku lat 90., tworzących dekadę w literaturze przedmiotu określaną mianem wojennej transformacji (ratna tranzicija), wszystkie strony konfliktu w oficjalnym dyskursie dążyły do deprecjacji i wymazania z pamięci doświadczenia socjalistycznej wspólnoty narodów, której istnienie, w myśl nowej politycznej wykładni, doprowadziło do skolonizowania narodowych tożsamości tworzących ją krajów i pozbawiło je politycznej podmiotowości. Konsekwencją tak zorientowanej polityki była marginalizacja czy wręcz dążenie do wyrugowania z przestrzeni publicznej obiektów jednoznacznie kojarzących się z SFRJ. Nic zatem dziwnego, że w okresie wojny ofiarą politycznej amnezji stały się również Muzeum 25 Maja i Dom Kwiatów.

Z drugiej strony, zwłaszcza w obliczu nierozstrzygalnego sporu dotyczącego sukcesji po Ticie, z upływem czasu coraz wyraźniej zaczęło pobrzmiewać przekonanie, że pamięć o Jugosławii należy (choćby w zmumifikowanej formie) ocalić. „Osierocone” Centrum Memorialne im. Josipa Broza Tity nie mogło przetrwać w dotychczasowej formie organizacyjnej, niemniej to właśnie wyłonione zeń instytucje stały się odpowiedzialne za przekodowanie historycznego doświadczenia i jego adaptację do nowych warunków. Stąd też newralgiczne okazało się w tym okresie pytanie, co właściwie powinno być prezentowane w belgradzkim muzeum i według jakiej formuły wystawienniczej ma ono działać. Kwestię tę uczyniono przedmiotem debat specjalistów, ale także obiektem zainteresowania politycznych gremiów. Reorganizacja strukturalnych podstaw i rewizja ideowych założeń

państwa, a udział przedstawicieli władz Serbii w ceremonii usankcjonował jego pozycję w ramach aktualnej, oficjalnej polityki pamięci, w której stosunek do dziedzictwa socjalistycznej federacji pozostaje nadal niedookreślony i pełen sprzeczności (serbscy politycy tak samo zgodnie potępiają komunistyczną metrykę reżimu Tity, jak i chętnie identyfikują się z jego państwotwórczą charyzmą oraz imperialnymi aspiracjami). Ponadto obecność grobów stawia w dwuznacznym świetle działalność w tym miejscu, przy kasie z biletami wstępu, sklepiku z pamiątkowymi, często prześmiewczymi gadżetami.

${ }^{20}$ Zob. relację ze zdarzenia: https:/www.youtube.com/watch?v=zpDEDYrDYIo (dostęp 26. 04.2018). 
funkcjonowania placówki stanowiły conditio sine qua non dalszej aktywności muzealnej. Eksperci byli zgodni co do jednego - ramą projektowanych przeobrażeń powinny być znaczeniowe przesunięcia w świadomości społecznej, przemodelowanie struktury interpretacyjnej, co umożliwiłoby ośrodkowi dalszą pracę na nowych zasadach, a także określiło kierunek jego publicznej recepcji.

Interesujących informacji na temat przebiegu dyskusji dotyczących przyszłości belgradzkiej instytucji dostarcza protokół ze spotkania pod tytułem Memorijalni centar ,, Josip Broz Tito" - Kako dalje? (Centrum memorialne im. Josipa Broza Tity - co dalej?), które odbyło się 6 listopada 1992 roku w Muzeum 25 Maja. Rzecz znamienna - debatę zorganizowało Towarzystwo Historyków Sztuki (Društvo istoričara umetnosti) we współpracy z pracownikami centrum ${ }^{21}$. Oprócz muzealników i historyków sztuki uczestniczyli w niej także doradca ministra oświaty i kultury, odpowiedzialni za urbanistyczne planowanie miasta reprezentanci ratusza oraz przedstawiciele mediów kulturalnych. Nacisk na kulturalny oraz informacyjny charakter przyszłej działalności ośrodka, czy to - jak proponowano - w postaci muzeum historycznego, muzeum nauki i techniki, czy też w formie akademii sztuk stosowanych albo multimedialnego edukacyjnego ,YU-centrum”, był spowodowany obawą, że zbytnia polityzacja wpłynie negatywnie na prace związane z ochrona, konserwacją i publicznym zagospodarowaniem cennego muzealnego depozytu. Planowe włączenie obiektów w infrastrukturę oraz ofertę turystyczną, wzorem innych krajów postsocjalistycznych, miałoby dopomóc depolityzacji pozostającej ich domeną, ,jugosłowiańskości”, przy czym nie próbowano wówczas definiować zakresu tego pojęcia w odniesieniu do działalności placówki, a także nie podjęto kwestii dotyczących przedmiotu oraz strategii budowania muzealnej narracji o przeszłości w warunkach głębokiego kryzysu jugosłowiańskiej tożsamości zarówno w jej wymiarze politycznym, jak i kulturowym. Skoncentrowano się zatem na potrzebie zmiany formuły organizacyjno-administracyjnej ośrodka (wymuszonej przez postępującą na skutek rozpadu SFRJ decentralizację i obarczoną wypaczeniami rekonfigurację sieci instytucjonalnej). Potraktowana instrumentalnie zmiana okazała się jednak trudna do realizacji, a właściwie - bez głębokiej reformy struktur znaczeniowych - na dobrą sprawę niemożliwa.

\section{„Muzeumifikacja"22}

W 1996 roku na mocy decyzji rządu Jugosławii rozstrzygnięto o losach Centrum Memorialnego. Po połączeniu administracyjnym Muzeum 25 Maja z Muzeum Rewolucji Narodów i Narodowości Jugosławii (Muzej revolucije naroda i narodnosti Jugoslavije) znajdującym się przy placu Nikoli Pašicia (czyli dawnym placu Marksa i Engelsa), nowej instytucji nadano status ośrodka kulturalnego i przemianowano na Muzeum Historii Jugosławii, przypieczętowując w ten sposób tematyczną orientację placówki. Z kolei wchodzą-

${ }^{21}$ Okrugli sto Memorijalni centar ,Josip Broz Tito” - kako dalje? Muzej „,25. maj”, 6. Novembar 1992, oprac. Društvo istoričara umetnosti Srbije - izvršni odbor, 12.11.1992 [maszynopis udostępniony przez Muzeum Jugosławii].

${ }^{22}$ Ironiczny termin muzeumifikacja, który w odniesieniu do interesującego mnie przypadku rozumiem jako petryfikację przekazu historyczno-kulturowego, jaka dokonuje się w muzealnych ramach, zaczerpnęłam z monografii Piotra Piotrowskiego Muzeum krytyczne, Poznań 2011, s. 13. 
ca dotąd w skład kompleksu prezydencka rezydencja, Dom Myśliwski, sala bilardowa, a także pawilon z kolekcją pamiątek zostały uznane za państwowe obiekty reprezentacyjne i oddane do użytku prezydentowi Federacyjnej Republiki Jugosławii ${ }^{23}$, Slobodanowi Miloševiciowi. Mieszkał on w rezydencji Josipa Broza do roku 1999, kiedy to budynek został zburzony podczas bombardowań Jugosławii przez NATO, w wyniku czego serbski przywódca przeniósł się do Budynku Owalnego, specjalnie przysposobionego do tego celu.

Komentarza wymaga kontrowersja związana $z$ decyzją o oddaniu rezydencji do dyspozycji Miloševiciowi. Paradoks sytuacji polega na subwersywnym naruszeniu ciagłości ideowego przesłania, którego cały kompleks miał być ucieleśnieniem. Oto bowiem - jak zauważa Lada Stevanović - w domu głównego architekta wspólnego, wielonarodowego państwa zamieszkał uzurpator i fałszywy sukcesor polityki jugosłowiańskiej, który w imię nacjonalistycznych racji doprowadził do rozpadu federacji i wybuchu bratobójczej wojny ${ }^{24}$. Stosunek Miloševicia do Tity, ogólnie rzecz ujmując, można uznać za schizofreniczny. $\mathrm{Z}$ jednej strony w czasach jego rządów w oficjalnym przekazie Josipa Broza uznawano za wroga serbskiego narodu, „zjugoslawizowanego" Chorwata dążącego do ograniczenia potencjału Serbii na rzecz wzmocnienia innych republik, z drugiej zaś wywodzący się z partii komunistycznej Milošević aspirował do miana politycznego następcy marszałka, uzasadniając działania militarne podejmowane przez Serbów w objętych wojną rejonach hasłem obrony Jugosławii, a także usiłując zaadaptować do swych rządów wypracowany w czasach SFRJ model autorytarnego przywództwa. Osobliwą kulminacją tej sukcesji à rebours stało się w marcu 2006 roku wystawienie zamkniętej trumny ze zwłokami Slobodana Miloševicia w jednej z sal ekspozycyjnych Muzeum 25 Maja, przekształconej na potrzeby tego wydarzenia w swego rodzaju kaplice. Co - dodajmy - uczyniono wbrew woli ówczesnej dyrektorki Ljiljany Cetinić, która uznała decyzję władz państwa za pogwałcenie suwerenności instytucji i naruszenie kulturalnego charakteru jej aktywności poprzez polityczną instrumentalizację ${ }^{25}$. W ciagu dwóch dni publicznej komemoracji przed budynkiem ustawiały się długie kolejki pogrążonych w żałobie obywateli, którzy chcieli osobiście oddać hołd zmarłemu (w więzieniu w Hadze) prezydentowi. Wśród nich byli też tacy, którzy w 1980 roku z równym oddaniem żegnali Titę.

Na początku XXI wieku względną stabilność instytucjonalną Domowi Kwiatów zapewniał ruch turystyczny, zarówno ten spod znaku jugonostalgii (w tym wypadku najliczniej grób marszałka nawiedzali Słoweńcy, choć nie brakło też Bośniaków, Czarnogórców, Serbów i Macedończyków), jak ten będący wyrazem zainteresowania lokalną historią i kulturą ze strony gości zagranicznych, niepochodzących z krajów pojugosłowiańskich. Standardowy program turystyczny oprócz wizyty w mauzoleum marszałka przewidywał zwiedzanie stałych ekspozycji pałek sztafetowych i darów, turyści docierali też do pobliskiego Muzeum 25 Maja w miarę regularnie organizującego tematyczne wystawy czasowe. Zarówno rozpoznawalność jugosłowiańskiego przywódcy komunistycznego na świecie, jak i kontrowersje narosłe wokół jego osoby z jednej strony cieszącej się uznaniem i ota-

${ }^{23}$ Socjalistyczna Federacyjna Republika Jugosławii po rozpadzie i odłączeniu Słowenii, Chorwacji, Macedonii oraz Bośni i Hercegowiny przekształciła się w 1992 roku w Federacyjną Republikę Jugosławii (tzw. trzecia Jugosławia), od 2003 do 2006 roku w Związek Państw Serbii i Czarnogóry.

${ }^{24}$ Л. Стевановић, Реконструкиија..., s. 112.

${ }^{25}$ Ibidem. 
czanej parareligijnym kultem, z drugiej zaś potępianej i odrzucanej, sprawiły, że w tym okresie kompleks muzealny na Dedinju - mimo braku inicjatyw modernizacyjnych oraz strategii promocyjnych - stanowił najchętniej odwiedzane miejsce z turystycznej oferty Belgradu $^{26}$, a według szacunków dotyczących publiczności, sporządzanych przez pracowników ośrodka był także najpopularniejszą instytucją kultury na obszarze dawnej Jugosławiii ${ }^{27}$.

Rosnące zainteresowanie odbiorców z zewnątrz pomagało placówce przezwyciężać stagnację, która wynikała z kryzysu politycznego i ekonomicznego państwa. Bezpośrednio zła kondycja ośrodka była pochodną negatywnej reputacji miejsca kojarzonego z Miloševiciem, ale przede wszystkim wynikała z rozproszenia muzealnych zbiorów, niemożności odzyskania ich dużej części, niewystarczającej przestrzeni magazynowej i złego zagospodarowania depozytów, do których personel muzeum miał mocno ograniczony dostęp. W tej sytuacji popularność Muzeum Historii Jugosławii wśród cudzoziemców, których oprócz chęci zdobycia wiedzy przyciagała także otaczająca Dom Kwiatów aura nieoczywistości czy wręcz osobliwości, można było uznać za tymczasowo zadowalające antidotum na słabe zainteresowanie obiektem ze strony lokalnej publiczności. Dystans mieszkańców Belgradu stanowił m.in. konsekwencję oficjalnej polityki historycznej, stawiającej w centrum dzieje narodu serbskiego i wykluczającej inność/różnorodność. W jej świetle temat socjalistycznej wielonarodowej federacji i uwikłania Serbów w projekt jugosłowiański jawiły się jako niewygodne, sprzeczne z aktualnym ideologicznym status quo państwa serbskiego, a także zagrażające integralności narodowej wspólnoty restytuowanej poprzez aktualizację tradycji przedjugosłowiańskich. Obłożenie anatemą okresu SFRJ sprawiło, że Muzeum Historii Jugosławii weszło w fazę swoistej hibernacji, czego odzwierciedleniem była zachowawcza polityka ekspozycyjna.

Brak wyrazistej koncepcji programowej i niepewność przyszłości placówki naturalną koleją rzeczy prowadziły do zubożenia jej oferty kulturalnej i edukacyjnej, a także były powodem, dla którego przestrzenie muzealne często wykorzystywano do organizacji imprez zewnętrznych, związanych lub częściej niezwiązanych z metryką i charakterem tego miejsca, takich jak Umbria Jazz Balkanic Window Festival czy Festiwal Nauki. Ten ostatni w 2008 roku stał się impulsem dla wicepremiera rządu Serbii, Božidara Ćelicia, do przypomnienia pomysłu, by przekształcić Muzeum Historii Jugosławii w centrum naukowo-techniczne, popularyzujące osiagnięcia nauk ścisłych. Celem tego przekształcenia miałaby być neutralizacja symbolicznych znaczeń kompleksu memorialno-muzealnego, pozbawienie go konotacji i funkcji politycznych, dodajmy, zadekretowane mocą decyzji politycznej. Ankieta przeprowadzona na zamówienie stacji radiowo-telewizyjnej B92 przez agencję Strategic Marketing wykazała, że 45\% respondentów opowiada się pozytywnie za tą zmianą, 24,5\% jest przeciwnych, a 30,5\% nie ma zdania. Serbska historyczka, Olga Manojlović Pintar, krytycznie oceniła koncepcję przekształcenia muzeum historycznego w ośrodek naukowo-techniczny, twierdząc, iż dowodzi ona niezdolności serbskich elit i społeczeństwa do konfrontacji z nieodległą przeszłością, postrzeganą jako trudna, konfliktogenna, a pod

\footnotetext{
${ }^{26}$ Paradoksalnie tej popularności Domu Kwiatów i Muzeum Historii Jugosławii przysłużył się także kryzys muzealnej infrastruktury (jego najdotkliwszymi przykładami stała się trwająca od 2001 roku renowacja siedziby Muzeum Narodowego i zapoczątkowana w 2007 roku rekonstrukcja belgradzkiego Muzeum Sztuki Współczesnej, zakończona dopiero po 10 latach), a ponadto niedofinansowanie oraz brak modernizacji innych placówek podlegających państwu - będącej wszakże podporą nowoczesnego turyzmu.

27 Л. Стевановић, Реконструкција..., s. 110.
} 
wieloma względami wręcz traumatyczna. To z kolei hamuje proces przewartościowania postaw polityczno-ideowych z lat 90., a tym samym uniemożliwia zmianę społeczną niezbędną dla realnej demokratyzacji ${ }^{28}$. Serbska polityka tworzenia nowego uniwersum kulturowego poprzez wymazywanie z pamięci niewygodnych treści, której przejawem był zamysł transformacji lieu de memoire w lieu d'oubli, czyli miejsce zapomnienia ${ }^{29}$, opierała się na strategii zerwania. Zmierzała ona do restytucji ciągłości tradycji interpretowanej w kluczu wartości etniczno-narodowych i właściwych jej symboli. W tak zdefiniowane społeczne imaginarium niemożliwe wydawało się włączenie obarczonego resentymentem dziedzictwa SFRJ, które w ten sposób pozostawało zaledwie negatywnym układem odniesienia $^{30}$.

Ponieważ tradycyjnie rozumiane muzeum nobilituje swój przedmiot i sankcjonuje jego obecność w przestrzeni publicznej, w związku z tym zaproponowano, by belgradzkiej placówce przydzielić całkiem nowe, najlepiej neutralne ideologicznie zadania. W istocie rzeczy pod maską nowoczesnego, racjonalnego i funkcjonalnego rozwiązania, jakim zdawało się utworzenie ośrodka rekreacji lub muzeum techniki, kryje się prosta (a zarazem koniunkturalna) ikonoklastyczna intencja, by poprzez wyrugowanie z percepcji społecznej obciążonego kontrowersyjnymi skojarzeniami materialnego obiektu (znaku) i przekształcenie jego semantyki za pomocą urzędowego dekretu oraz wymiany instytucji zdeprecjonować jego znaczeniowy desygnat i zneutralizować społeczne oddziaływanie.

\section{Między fetyszyzacją pamięci a „dyskursywizacją” muzeum}

W warunkach, w których budulcem oficjalnego kanonu stała się narodowa historia, spartykularyzowana i utożsamiona z serbskocentrycznym porządkiem pamięci, a dotychczasowa symboliczna legitymizacja belgradzkiego muzeum jako muzeum historii Jugosławii została unieważniona, jedyną racją istnienia instytucji pozostawał legat Josipa Broza Tity - rozproszona, w dużej mierze zaniedbana i wyjęta spod kurateli muzealnych specjalistów kolekcja. Jak już wspominałam, to ona była zaczynem procesu instytucjonalizacji, wyznaczyła kierunek organizacji aktywności wystawienniczych i pozostała fundamentem języka belgradzkiego muzeum jako muzeum historycznego. Na początku istnienia placówki - która, przypomnijmy, powstała jako depozyt pałek sztafetowych z obchodów Dnia Młodości (1956-1987), odznaczeń, prezentów dyplomatycznych, dzieł sztuki, zbiorów numizmatycznych, fotografii, kart, dyplomów, listów gratulacyjnych, laurek od dzieci, plakatów, znaczków pocztowych, rzeczy osobistych oraz innych artefaktów związanych z osobą Josipa Broza Tity - kolekcja stanowiła materialną osnowę ekspozycji. Jej podstawowym celem była nie tylko konkretyzacja i naoczne przedstawienie abstrakcyjnych treści ideowych, ale przede wszystkim uprawomocnienie i afirmacja rządów jugosłowiańskiego przywódcy, a także udział w kreacji jego wizerunku, a po śmierci kultywowanie pamięci

${ }^{28}$ Л. Стевановић, Реконструкиија..., s. 114.

${ }^{29}$ Por. M. Todorova, Dizanje prošlosti u vazduh. Mauzolej Georgi Dimitrova kao lieu de mémoire, [w:] Eadem, Dizanje prošlosti u vazduh. Ogledi o Balkanu i Istočnoj Evropi, przeł. S. Glišić, Beograd 2010, s. 148.

${ }^{30}$ Skrajnym przykładem tego rodzaju czyszczenia pamięci - w imię retroaktywnie projektowanej zbiorowej tożsamości, stało się w roku 1999 wysadzenie w powietrze mauzoleum Georgi Dymitrowa w Sofii. Zob. M. Todorova, Dizanje..., s. 139-175. 
o nim. Zogniskowanie narracji wokół przedmiotów traktowanych niczym wota czy relikwie, ekstensje obecności marszałka bądź świadectwa jego charyzmy prowadziły do fetyszyzacji przekazu o przeszłości i utrwalenia wyobrażeń o jej centralnej postaci w formie idolatrii.

Dopiero z czasem sama kolekcja stała się obiektem krytycznego namysłu zarówno jako jedyna w swoim rodzaju reprezentacja uwierzytelniająca historyczne doświadczenie, ale też jako materia produkcji znaczeń (semiozy) bądź temat refleksji metaekspozycyjnej. Owo przeprogramowanie porządku konceptualnego, w ramach którego muzealny depozyt zaczął funkcjonować na kolejnym etapie swej biografii, tj. w warunkach demokratycznej transformacji ustroju państwa, było niezbędne do tego, by Muzeum Historii Jugosławii mogło stać się instytucją nowoczesną, decentralizującą i pluralizującą pamięć.

Przełomem w refleksji nad formułą działania i relacjami Muzeum Historii Jugosławii z publicznością stała się wystawa Smrt u trezoru (Śmierć w skarbcu), zorganizowana w 2009 roku pod kierunkiem kuratorów Momy Cvijovicia i Any Panić ${ }^{31}$. Przedsięwzięcie miało charakter autotematyczny - intencją twórców była nie tylko prezentacja dotychczasowej działalności, lecz także postawienie podstawowych pytań dotyczących funkcjonowania muzeum w nowych warunkach historyczno-politycznych ${ }^{32}$, możliwości modernizacji programu oraz metod opracowania i prezentacji zbiorów muzealnych ${ }^{33}$. Wystawa, a także towarzyszące jej imprezy publiczne i specjalistyczne działania muzealne miały być podstawą do podsumowania przeszłości i początkiem nowego rozdziału w dziejach instytucji. Zarówno obszar zainteresowania, jak również sposób opracowania i prezentacji zbiorów wymagały nowoczesnego podejścia, czyli uruchomienia perspektywy interdyscyplinarnej - kulturowej, antropologicznej i socjologicznej - a przede wszystkim postawy krytycznej.

Ocenę ówczesnej kondycji Muzeum Historii Jugosławii sugerował już sam tytuł wystawy Smrt u trezoru (Śmierć w skarbcu). Oczywiście można go było odnieść do postaci Tity, pochowanego (niczym władcy starożytnego Egiptu) w otoczeniu przedmiotów będących znakiem jego pozycji, prestiżu i kultu, lub też do „,faraonizmu”, jaki w opinii potocznej cechował styl jego autorytarnych rządów. Jednak zgodnie z intencją twórców ekspozycji jej tytuł miał wskazywać w pierwszym rzędzie na omówiony wyżej proces muzeumifikacji instytucji oraz losy kolekcji - zaniedbanej i skazanej na dewastację w związku z niedostępnością eksponatów. Te bowiem umieszczono w różnych miejscach, m.in. ich znaczna, najcenniejsza część pozostała w magazynach Budynku Owalnego, mimo że muzeum zostało z niego wysiedlone siłą w 1997 roku i przejęte na potrzeby ówczesnego prezydenta $^{34}$. Co więcej, utraciło też trzy inne obiekty dotychczas należące do Centrum

${ }^{31}$ Od 2006 roku sytuacja placówki zaczęła się stabilizować w wymiarze administracyjnym. Po secesji Czarnogóry Serbia stała się suwerenną republiką i dysponentem wielu instytucji dotąd wspólnych dla obu krajów federacji. Wówczas to została zatwierdzona decyzja o powołaniu Muzeum Historii Jugosławii jako instytucji państwowej, podległej Republice Serbii. Od tej pory obejmuje ona Dom Kwiatów z otaczającym go Parkiem Rzeźby oraz przestrzenie wystawiennicze w Starym Muzeum, oraz Muzeum 25 Maja.

${ }^{32}$ Roboczy tytuł wystawy brzmiał 6. oktobar MIJ (6 października MHJ) i odnosił się do dnia po przewrocie 5 października 2000, kiedy to zostały obalone rządy Slobodana Miloševicia. Data 6 października zyskała rangę symbolicznego początku demokratycznych przemian w Serbii.

${ }^{33}$ A. Panić, M. Cvijović, Izložba Smrt u trezoru 27.06.2009-23.08.2009 [katalog wystawy], Beograd 2009, s. 10 .

${ }^{34}$ W Domu Owalnym, który wzniesiono na kilka miesięcy przed śmiercią Josipa Broza, w 1982 roku zdeponowano najcenniejsze eksponaty historyczne i artystyczne ze zbiorów jugosłowiańskiego prezydenta i nazwano je kolekcją pamiątkową (spomen zbirka). Była dostępna dla zwiedzających w latach 1984-1996. Kiedy po 
Memorialnego, choć przecież na mocy decyzji rządu przejęło także pokaźne zbiory Muzeum Rewolucji i zostało zobowiązane do ich ochrony. To rozproszenie muzealiów znacząco utrudniało pracownikom prowadzenie działań konserwatorskich i specjalistycznych badań, a tym samym ograniczyło możliwość ich publicznej prezentacji. Dopiero w 2003 roku, czyli w roku śmierci osadzonego w Hadze Miloševicia, przy okazji przygotowań archeologicznej wystawy Do, ut des muzealnikom zezwolono na zweryfikowanie stanu depozytu w magazynie Domu Owalnego. Po raz kolejny o sytuacji belgradzkiego muzeum zadecydowały wydarzenia polityczne.

Emblematem omawianej ekspozycji w 2009 roku stała się zabytkowa figura z VI w. p.n.e., przedstawiająca Ozyrysa, egipskiego boga umarlych i odrodzonego życia, podarowana Ticie przez prezydenta Anwara el-Sadata. Z kolei osią muzealnej opowieści o losach niepowtarzalnego w skali regionu legatu Josipa Broza Tity uczyniono „życie po życiu” czternastu wybranych przedmiotów - nielicznych, które w latach 1992-2009 wzbudziły zainteresowanie i/lub zostały wykorzystywane na potrzeby działań artystycznych lub nauki przez reżyserów (Gorana Markovicia i Dušana Makavejeva), architekta (Bogdana Bogdanovicia), muzealniczkę (Suzanę Milovanović), historyka sztuki (Nenada Radicia) i in., co pozwoliło przedłużyć egzystencję tych artefaktów, ożywić je w nowych kontekstach, nadać nowe znaczenia ${ }^{35}$. Dlatego też na wystawie Smrt u trezoru o prezentowanych obiektach informowały nie tylko standardowe etykiety, ale przede wszystkim opowiadali ludzie, których komentarze zarejestrowano na filmie. Skonfrontowano w ten sposób „suchy” tekst muzeologiczny z zapisem historii przeżytej, utrwalonej w osobistym wspomnieniu. Wystawa miała wydobyć indywidualny charakter zbiorów muzeum, ukazać niecodzienne biografie wybranych przedmiotów, a także stanowić impuls dla autokrytycznej refleksji, stanowiącej próg w procesie negocjacji jego tożsamości jako instytucji publicznej. Chodziło o przewartościowanie dotychczasowego, hieratycznego i, by tak rzec, statycznego podejścia do eksponatu jako nośnika historycznej informacji oraz myślenia o muzeum jako instytucji sprawującej kontrolę nad wartością i znaczeniami zbiorów, na rzecz takiego modus operandi, w którym artefakt - dawny rekwizyt kultu i element apologetycznych narratywów o jugosłowiańskim przywódcy - staje się znakiem większej dyskursywnej struktury, katalizatorem semiozy, a muzeum - machiną interpretacyjną.

Sens instytucjonalnej zmiany, jaka stała się udziałem Muzeum Historii Jugosławii na przełomie dwóch pierwszych dekad XXI wieku, polegał zatem na przejściu od trybu prezentującego, konserwującego znaczenia do problematyzującego, krytycznego sposobu traktowania materii historycznej; od politycznej legitymizacji dominującego porządku ideologicznego do polityczności pojmowanej jako aktywne uczestnictwo w dyskursywnym formowaniu świadomości społecznej oraz przestrzeni publicznej. Wśród wystaw czasowych, realizujących pierwszy typ strategii wystawienniczej - oparty na udostępnianiu zbiorów publiczności i relacjonowaniu przeszłości - można wymienić te organizowane przede wszystkim w pierwszej fazie istnienia muzeum w postaci Centrum Memorialnego. Są to m.in. Tito u partizanskoj štampi (1983; Tito w prasie partyzanckiej), Priznanja Titu - po-

\footnotetext{
bombardowaniu prezydenckiej rezydencji w 1999 roku przeprowadził się tu Slobodan Milošević wraz z rodziną, budynek został nazwany Willa „Pokój” (Vila „Mir”).

${ }^{35} \mathrm{O}$ zwrot niektórych cennych eksponatów po śmierci Tity zwrócili się darodawcy - przede wszystkim muzea z Serbii oraz dawnych republik Jugosławii - instytucje, z których pochodziły te przedmioty.
} 
velje i makete (1984/1985; Dowody uznania dla Tity - dyplomy i makiety), Tito i jugoslovenska socijalistička revolucija (1985; Tito i jugosłowiańska rewolucja socjalistyczna), Rastemo pod zastavom Tita - za srećan put XXI vek (1988; Dorastamy pod sztandarem Tity - na szczęśliwej drodze do XXI wieku), Nesvrstani od Beograda do Beograda (1989; Niezaangażowani od Belgradu do Belgradu), Do, ut des / Darovi i uzdarja (2003; Do, ut des / Dary i podarunki odwzajemnione); Put mira - makete i modeli iz kolekcjije MIJ (2003; Put mira - makiety i modele z kolekcji MHJ), Čestitamo - novogodišnje čestitke Josipu Brozu Titu (2004; Winszujemy - noworoczne życzenia dla Josipa Broza Tity), Svet od srebra (2008; Świat ze srebra) itp.

Zwiastunem przemiany formuły działania, oznaczającej ,dyskursywizację" ${ }^{\text {"6 }}$ belgradzkiego muzeum, stały się przedsięwzięcia wykraczające poza działalność ekspozycyjną, które animatorom tych przeobrażeń pozwalały myśleć o przyszłości ośrodka w kategoriach forum bądź wielozadaniowego think tanku. I tak w październiku 2001 roku w Muzeum 25 Maja zaprezentowane zostało przedstawienie Bordel ratnika (Burdel wojowników), zrealizowane przez Anę Miljanić na podstawie powieści Miroslava Krležy Zastave (Flagi) oraz esejów antropologicznych Ivana Čolovicia, od których to reżyserka zaczerpnęła tytuł spektaklu. Przesłaniem wydarzenia przygotowanego pod auspicjami Centrum Dekontaminacji Kulturowej (Centar za kulturnu dekontaminaciju) twórcy uczynili pytanie o etyczną odpowiedzialność elit umysłowych za wojnę w Jugosławii - była to jedna z pierwszych w wymiarze regionu inicjatyw służących problematyzacji doświadczenia życia w Jugosławii oraz fenomenu jugosłowiańskości, jednoznacznie wskazująca na konieczność intelektualnego przepracowania tych kwestii ${ }^{37}$.

To nowoczesne myślenie o muzeum domagało się również przekształcenia dotychczasowych (nieefektywnych) form społecznego oddziaływania, m.in. poprzez otwarcie ośrodka na zadania związane z aktywizacją przestrzeni publicznej. W 2007 roku w ramach projektu Public Space 4 Public Art grupa studentów Wydziału Architektonicznego Uniwersytetu w Belgradzie zaproponowała różne koncepcje modernizacji historycznego obiektu, na trwałe wpisanego w historyczny i kulturowy pejzaż miasta, poddając go „,artystycznej chemii" za pomocą przekształceń architektonicznych, designu, pop-artu, performansu oraz turystycznego marketingu ${ }^{38}$. Punktem wyjścia stała się następująca diagnoza: Muzeum Historii Jugosławii - potraktowane z jednej strony jako oficjalna instytucja, z drugiej zaś jako locus pamięci zbiorowej - ujawnia silne napięcie między tym, co oficjalne, a tym, co publiczne. W tych warunkach sztuka może okazać się dla muzealnych praktyk dobrym, bo angażującym poznawczo poprzez wartości estetyczne, medium. Reorganizacja i resemantyzacja przestrzeni wystawienniczych oraz ich otoczenia miałaby - zgodnie z koncepcjami młodych twórców - uatrakcyjnić je nie tylko pod względem turystycznym z myślą o przyjezdnych, ale także rekreacyjnym, czyli oddać w użytkowanie mieszkańcom Belgradu. Pod tym kątem projekt odpowiadał założeniom community art - nurtu, który za pomocą artystycznych interwencji dokonywanych w sferze publicznej chce modelować międzyludzkie relacje. W omawianym przypadku chciano tego dokonać poprzez zintegrowanie na nowo

\footnotetext{
${ }^{36}$ Pojęcie dyskursywizacji w odniesieniu do procesu przekształcania muzeów w instytucje krytyczne wprowadza Piotr Piotrowski w pracy Muzeum krytyczne...

${ }^{37}$ Рог. Л. Стевановић, Реконструкиија..., s. 111.

${ }^{38}$ Dokumentację tego projektu opublikowano w postaci katalogu: Z. Đukanović, J. Živković, A. Bobić, Public Art 4 Public Space 2007, Beograd 2008.
} 
instytucji z miastem za pośrednictwem komponentu (re)kreacyjności i partycypacji. I choć Public Space 4 Public Art pozostał tylko zapisem pewnej koncepcji, niewcieloną w życie wizją, to jednak z całą mocą odzwierciedlał potrzebę radykalnych zmian i nakreślał ich kierunek.

Przedsięwzięcia „okołomuzealne” - będące zarówno pochodną namysłu nad kształtem instytucji, jak i symptomem przeobrażeń lokalnej kultury historycznej - a także zmiany personalne w Muzeum Historii Jugosławii utorowały drogę nowej polityce wystawienniczej. Za przykład niech posłużą wpisujące się w główny nurt tematyczny ekspozycje czasowe, takie jak: problematyzująca jugosłowiański kult jednostki Efekat Tito. Harizma kao politička legitimizacija (Efekt Tito. Charyzma jako legitymizacja polityczna), zorganizowana w 2009 roku pod kierunkiem Mariny Dokmanović, m.in. we współpracy z proobywatelskimi organizacjami: Fundacją B92, Centrum Kulturalnym „Reks”, czy wystawy ukazujące zjawiska z zakresu jugosłowiańskiej kultury artystycznej Velika iluzja. Tito i 24 miliona metara filmske trake (2014, Wielka iluzja. Tito i 24 miliony taśmy filmowej), opowiadająca o kinematografii oraz Dizajn za novi svet (2016, Design dla nowego świata), dotycząca wzornictwa $\mathrm{z}$ epoki SFRJ. Każda z nich na swój sposób podejmuje dyskusję zarówno z fenomenem jugosłowiańskiej kultury władzy - opartej na charyzmie i autorytarnych rządach Josipa Broza, jak też ironicznie odnosi się do estetyki jugonostalgii, dominującej dziś w potocznej percepcji i ocenie minionej epoki oraz chętnie przyswajanej przez przemysł turystyczny, który łatwo przekształca pamięć w atrakcję, w towar. Wspomniane wystawy opracowywane były metodami naukowymi, jako rodzaj przedsięwzięć badawczych, a jednocześnie z dużą dbałością o wizualny aspekt prezentacji przeszłości. Takie podejście wynika - jak się zdaje - nie tylko z konieczności dostosowania się do współczesnej wrażliwości percepcyjnej i nowoczesnych możliwości technologicznych, ale także ze znaczącego udziału historyków sztuki w pracach kuratorskich - Any Panić, Mariji Đorgović, Nenada Radicia i innych. Przesunięcie akcentu z oglądu historycznego, rekonstrukcyjnego na perspektywę fenomenologiczną oraz poszukiwanie twórczego kontaktu z przeszłością zaowocowało kolejną zmianą nazwy pod koniec 2016 roku, tym razem na Muzeum Jugosławii ${ }^{39}$.

Rodzi się w tym miejscu pytanie o funkcje estetyzacji obrazu przeszłości. Jak dalece jest ona programowaniem łatwego efektu poprzez redukcję wyobrażenia o budzącej kontrowersje historii do atrakcyjnych, przykuwających uwagę i budzących nostalgię ,wyglądów", do specyficznego dla niej idiomu ikonograficznego/wizualnego, a w jakim stopniu ten typ przedstawienia uruchamia poznawczy i krytyczny potencjał ekspozycji. Wydaje się, że kompozycja muzealnego przekazu, polegająca na rekonstrukcji stylu epoki i zmierzająca do umożliwienia odbiorcy zmysłowego kontaktu z przeszłością - nie wyczerpuje intencji kuratorów. Kluczem jest tu język wystawy, który odwołuje się do doświadczeń nowoczesnej sztuki jako alternatywnego pola myślenia, jako obszaru intelektualnego eksperymentu wyrażanego $\mathrm{w}$ formach wizualnych. Jest on we wspomnianych ekspozycjach narzędziem nie tylko poruszania zbiorowej wyobraźni i angażowania emocji, ale także instrumentem ożywiania znaczeń. Muzeum staje się tu ekranem, na który projektowane są obrazy, by poprzez unaocznienie odległych, a często także abstrakcyjnych treści uruchamiać

\footnotetext{
${ }^{39} \mathrm{Na}$ temat współczesnych procesów muzealizacyjnych jako symptomie przemian stosunku do przeszłości zob. m.in. B. Korzeniewski, Muzealizacja a późnonowoczesna przemiana stosunku do przeszłości, „Kultura Współczesna", 2004, nr 2 (40), s. 24-34.
} 
i wytwarzać wiedzę. Jednocześnie dzięki tym zabiegom, mającym wyraźnie metaikonograficzny charakter, działalność Muzeum Historii Jugosławii zyskuje walor autokrytycyzmu, którego celem jest rewizja własnej tradycji, konfrontacja z wytworzonym przez siebie kanonem wystawienniczym, a także ciągła dekonstrukcja muzealnych narracji i ich ideologicznych wykładni.

Jak wynika z powyższych rozważań, przeobrażenia Muzeum Historii Jugosławii odzwierciedlają przebieg transformacji systemowej, ujawniając jednocześnie lokalną (przede wszystkim serbska, ale też regionalną) specyfikę tych procesów. Zasadnicza zmiana modelu instytucjonalnego w omawianym przypadku oznacza po pierwsze, przejście od ideologicznej monologiczności przekazu historycznego do jego dyskursywizacji, która ma wspierać zdialogizowaną wizję przeszłości, jej krytyczną interpretację; po drugie zaś, przekształcenie przestrzeni oficjalnej - stanowionej mocą rytuału i konsekrowanej bezpośrednią obecnością władzy w przestrzeń publiczną, implikującą zaangażowanie i dyskusję społeczna. Stało się to możliwe dopiero w pierwszej dekadzie XXI wieku, czyli w warunkach demokratyzacji państwa oraz dzięki adaptacji sprawdzonych w krajach europejskich wzorców organizacji kultury, przemodelowaniu pola intelektualnego i aksjologicznego, a także otwarciu na nowe metody muzealnicze.

Warto w tym miejscu zaznaczyć, że z perspektywy badań komunizmu o filozofii działania Muzeum Jugosławii mówi nie tylko to, jakie obszary pamięci zostają przezeń unaocznione (jugosłowiańska kultura władzy, realizowany w SFRJ projekt modernizacyjny, jugonostalgia), ale też to, jakie treści są tu przemilczane i wyłączone z rejestru widzialności, kształtowanego za pośrednictwem muzealnej praktyki. Mam na myśli opresyjność systemu politycznego, zapaść ekonomiczną, napięcia narodowościowe, a wreszcie rozpad państwa, innymi słowy, ciemną stronę komunistycznego doświadczenia, która w innych krajach dawnego bloku wschodniego stała się domeną działalności tego rodzaju placówek, stanowiących zarówno instytucjonalną ramę społecznej świadomości historycznej, jak i narzędzie rozrachunku z przeszłością.

\section{Bibliografia}

Bobić A., Đukanović Z., Živković J., Public Art 4 Public Space 2007, Beograd 2008.

Bogusławska M., Kuća na promaji. Szkic o mauzoleum Josipa Broza Tity, [w:] Znaczqce przestrzenie Słowiańszczyzny, red. J. Goszczyńska, G. Szwat-Gyłybowa, Warszawa 2010, s. 53-95.

Connerton P., Jak społeczeństwa pamiętaja, przeł. M. Napiórkowski, Warszawa 2012.

Cvijović M., Panić A., Izložba Smrt u trezoru 27.06.2009-23.08.2009 [katalog wystawy], Beograd 2009.

Cvijović M., Uzdarja J. B. Tita kao sastavni deo razmene poklona praćena kroz arhivsku građu i protokole kabineta predsednika republike, maszynopis udostępniony przez autora, Beograd 2011.

Čolović I., Beograd: O maketama i štafetama, [w:] vlasTito iskustvo past present, R. Leposavić, Beograd 2005, s. 137-162 (polski przekład I. Čolović, O makietach i sztafetach, przeł. M. Petryńska, „Herito. Dziedzictwo, kultura, współczesność”, 2012, nr 7, s. 112-121).

Ignjatović A., Tranzicija i reforme: architektura u Srbiji 1952-1980, [w:] Istorija umetnosti u Srbiji u XX veku, t. 2: Realizmi i modernizmi oko hladnog rata, red. M. Šuvaković, Beograd 2012. 
Korzeniewski B., Muzealizacja a późnonowoczesna przemiana stosunku do przeszłości, „Kultura Współczesna", 2004, nr 2 (40), s. 24-34.

Kuljić T., Tanatopolitika. Socijološkoistorijska analiza političke upotrebe smrti, Beograd 2014.

Kultura wiedzy, red. P. Celiński, J. P. Hudzik, Kraków 2012.

Manifestacja zwolenników Vojislava Šešelja przed mauzoleum Josia Broza Tity https://www.youtube. $\mathrm{com} /$ watch?v=zpDEDYrDYIo, (dostęp 26.04.2018).

Okrugli sto Memorijalni centar ,Josip Broz Tito”-kako dalje? Muzej ,,25. maj”, 6. Novembar 1992, oprac. Društvo istoričara umetnosti Srbije - izvršni odbor, 12.11.1992 [maszynopis udostępniony przez Muzeum Jugosławii].

Pękala T., Performans i teatralizacja-pojęcia wędrujace, [w:] Teatr, teatralizacja, performatywność, red. T. Pękala, Lublin 2016.

Стевановић Л., Реконструкиија сећанја, конструкиија памћенја. Кућа иъвећа и Музеј историје Југославије, „Зборник Етнеграфског института САНУ”, nо 26: Спомен места - историја - сећаға, уред. А. Павићевић, Београд 2009, p. 101-116.

Указ о проглашеғу закона о употреби имена и лика Јосипа Броза Тита, „Службени лист Социјалистичке Федеративне Републике Југославије”, 28.09.1984, R. 40, no 51, p. 11791181.

Šuvaković M., Farenhajt 387. Teorijske ispovesti, Novi Sad 2006.

Piotrowski P., Muzeum krytyczne, Poznań 2011.

Todorova M., Dizanje prošlosti u vazduh. Mauzolej Georgi Dimitrova kao lieu de mémoire, [w:] Eadem, Dizanje prošlosti u vazduh. Ogledi o Balkanu i Istočnoj Evropi, przeł. S. Glišić, Beograd 2010, s. 139-175.

Magdalena Bogusławska - kulturoznawczyni, slawistka. Zajmuje się obszarem słowiańskich Bałkanów, przede wszystkim kulturą wizualną, widowiskami kulturowymi oraz praktykami artystycznymi. Interesuje się fenomenem socjalistycznej Jugosławii, jugosłowiańską kulturą władzy oraz pamięcią o komunizmie w krajach postjugosłowiańskich. Opublikowała m.in. monografie: Teatr u źródet. Teatr i dramat poludniowostowiański wobec tradycji widowiskowych regionu (Warszawa 2006) i Obraz władzy we władzy obrazu. Artystyczne konceptualizacje wizerunku Josipa Broza Tity (Warszawa-Kraków 2015). Pracuje w Instytucie Slawistyki Zachodniej i Południowej Uniwersytetu Warszawskiego.

ORCID 0000-0002-8900-0458 